\title{
Between weak markets and weak regulations: determinants of contracting in orchard farming in Albania
}

\author{
D. Imami ${ }^{1}$, E. Zhllima ${ }^{1}$ D. Viaggi ${ }^{2}$ and W. Bokelmann ${ }^{3}$ \\ ${ }^{1}$ Department of Agrifood Economics and Policy, Agriculture University of Tirana, Koder-Kamez, 1030 Tirana, Albania; \\ dimami@ubt.edu.al \\ ${ }^{2}$ Departmen. of Agricultural Sciences, Alma mater studiorum-University of Bologna, Giuseppe Fanin, 50, 40127 Bologna, Italy \\ ${ }^{3}$ Institute of Economics of Horticultural Production, Department of Agricultural Economics and Social Sciences, Humboldt University \\ of Berlin, Unter den Linden 6, 10099 Berlin, Germany
}

RESEARCH ARTICLE

\begin{abstract}
This paper analyses the relations and contracting behaviour of orchard farmers with their customers in Albania. The study is based on a structured farm survey, including information about relations and contracting with clients, and a cluster analysis aimed at identifying key farm typologies with respect to contracting. As expected, most farmers rely on spot transactions. Formal contracts are used sparingly due to a lack of interest from buyers, small farm size and lack of trust in contract enforcement. However, farmers commonly use informal agreements/contracts as a substitute for formal ones. The most common differences between those farmers who engage in contracting and those that do not concern household size, the number of years in orchard production, and the amount of losses incurred.
\end{abstract}

Keywords: farm contracting, two-step cluster, Albania

\section{Introduction}

The economic context and the agrifood sector are changing rapidly in developing and transition countries. Until the early 1990s, Albania was still a planned economy. In a matter of a few years it transited into a market economy, resulting in noticeable socio-economic changes in the country. These changes have affected agricultural production, marketing and distribution systems. During the last two decades, the entire Albanian agriculture sector has witnessed a prolonged expansion in the context of transition from collective farms to private holdings.

Fruit production (which is the subject of this study) is one of the most important and fastest growing agriculture subsectors in Albania. Production of fresh fruit has grown by 73.3\% since 2007 reaching 208,000 tonne in 2012 (MAFCP, 2013). The orchard sector has also been considered a priority sector by the Albanian government (MAFCP, 2007).

Apples are one of the main fruits in Albania in terms of cultivated area, production and consumption. Domestic production of apples has rapidly increased in recent years more than quadrupling between 2000 and 2010. Production is expected to further increase in the coming years, due to new plantations resulting from the incentives provided by government investment support schemes, and motivation derived from high domestic consumer demand (Skreli and Imami, 2012). As production increases, market access is one of the main challenges faced by many farmers.

Most agriculture holdings in Albania are small (the average farm size is about $1.3 \mathrm{ha}$ ) and can be qualified as mixed and (semi) subsistence farms (MAFCP, 2013). This is also the case for most farms that cultivate orchards - only $1 \%$ of farms with orchards have more than 1 ha of area cultivated with orchards. Wholesalers play a crucial role in the fruit (and vegetable) value chain in Albania, given that both the production bases, on one hand, and the retail sector, on the other hand, are very fragmented. Accordingly, most fruit and vegetable production, including apples, is sold through wholesalers and wholesale markets. The main retail outlets for apples are 'green markets' (specialised in fruits and vegetables), while supermarkets still play a minor role in fruit and vegetable retail - only $5 \%$ of consumers in Tirana (main urban market) state that they buy apples mainly in supermarkets (Imami et al., 2012).

Changes to the institutional environment in Albania have also impacted the agriculture sector. As in other developing/ transition countries, state institutions are inefficient and law enforcement is weak, affecting the way the economy, 
markets, society and also the agriculture sector function. Corruption is perceived to be extremely high in the judicial system (Gallup, 2009; IDRA, 2010). Attitudes toward the institutions that guarantee the rule of law, such as civil courts, police and notaries, are embedded with distrust and perceptions of corruption and a lack of transparency (CRSSD, 2005; Stahl et al., 2009; World Bank, 2006). Therefore, the distrust in the courts (and law enforcement institutions) is expected to influence agrifood value chain governance significantly, and discourage formal contracting between actors in the value chain. Considering the informal and formal aspects of the Albanian institutional environment farmers are expected to be cautious when doing business and seek to safeguard their transactions with other actors in order to reduce risk exposure.

The objective of this research is to analyse the market access choices of orchard farmers in Albania. Our hypothesis is that most farmers do not use formal contracting due to their small size and due to the lack of trust in enforcement by all parties. In this context, farmers have to choose between 'spot markets' or engaging in informal/relational contracting that may serve as a substitute for formal contracts.

The main contribution of the paper is empirical in nature as, to the best knowledge of the authors, no previous studies have been undertaken on this subject in the context of Albania. Other authors have observed Albanian farmers' behaviour towards land transactions (Zhllima and Imami, 2012) or the factors influencing farmers' choices for cooperation and collective action (Skreli et al., 2011). Yet this is the first paper to analyse farmers' behaviour towards contracting in Albania. The findings are also expected to highlight new ideas for research studies in this field.

The paper is organised in three sections in addition to this one. Section 2 consists of the theoretical background and methods. Section 3 reflects the empirical research findings, while Section 4 provides the discussion, conclusions and recommendations.

\section{Theoretical background and methods}

\section{Theoretical background}

Governance forms range from (spot) market relationships, to hybrid governance forms (contracts), to vertical integration or hierarchy (meaning the bringing together of the activities of various companies within one legal entity) (Williamson, 1999). In this study we analyse spot market relations versus hybrid governance forms, formal or informal agreements or contracts. For a wider discussion of the definition of the types of agreements and contracts used in agriculture a valuable contribution is provided by Grandori (1997), Gulati (1998) and Almazan et al. (2011).

Contract farming is a significant institutional arrangement that facilitates market access for smallholders, especially when the transaction costs of direct market participation (spot markets) are high for producers and/or traders (Catelo and Costales, 2004). The theoretical framework of transaction cost economics emphasises that when transaction costs of spot markets are high, economic efficiency gains can be achieved by entering into various forms of vertical coordination rather than arranging sales on spot markets (Williamson, 1991). Contract farming is a common form of coordination in agrifood value chains. The definition of contract farming may vary from country to country depending on prevailing circumstances (FAO, 2001; Watts, 1994). In essence, there are two types of contract farming: formal contracts and informal contracts. In general, formal contracts are written contracts (e.g. between a farmer and a processing or trade company), whereas informal contracts are unwritten, but nevertheless binding agreements (FAO, 2001). The evidence suggests that larger farms prefer formal contracts, whereas informal contracts are more accommodating to the needs of smallholders (Fafchamps and Lund, 2003; Grimard, 1997). Transaction costs are higher for small farms, both for the farm themselves and for their partners in transactions or networks due to diseconomies related to small scale (high relative set-up costs of information systems and procedures). As a result, the transaction costs related to the search, evaluation, contract design and monitoring of contract execution are high. To compensate for this, small farms rely more on reputation mechanisms and on network contacts to support reputation mechanisms instead of detailed (formal) contracting (Nooteboom, 1999).

In addition to the agent (farm) size, another factor affecting the propensity to choose formal contracting is the legal enforcement framework. Bakucs et al. (2010) concludes that formal contractual relationships are less frequent when there is little trust in legal enforcement. In the case of weak institutional enforcement, farmers often prefer informal and self-enforcing arrangements (Bouis and Haddad, 1990; Jabbar et al., 2008). Williamson (1979) reflects directly on 'relational contracting' stating that an alternative choice to (formal) contracting is (informal) relational contracting which is 'a 'socially enforceable' contract, a completion of incomplete contingent contracting performed by sociallydefined, norm-driven definitions of proper behaviours, rather than by formal rules and hierarchy'. 


\section{Methods}

This paper is based on a survey targeting orchard farmers specialised in apple production. The survey consisted of structured questionnaires, which were designed based on an extensive literature review, and consultations with agricultural economists, scholars and practitioners. The questionnaires were initially tested with selected farmers and further improved after testing. The questionnaire intended to collect basic information about farm structure and production, farm household characteristics, relations with clients and farmer perceptions regarding the enabling environment. More specifically, it was organised in sections as follows: background, structure of market channels, sales and marketing behaviour, price and payment forms, information and transaction costs, physical asset specificity, and others such as access to services and subsidies, certification, etc.

As most apples are sold through wholesale markets in Albania (AAC, 2008), the easiest and most cost-effective way to identify (large) farms is to visit wholesale markets, especially during the production season. The survey was carried out during August and September 2010 in the largest agriculture wholesale markets of Albania, including the market of Korçë, Lushnje, Shkodër, and Tiranë. Farmers were approached randomly by four trained students. 179 orchard farmers specialised in apple production were interviewed (when farmers were approached, they were asked about their main crop/activity, and the interview was undertaken if apples were a main activity). Most interviews were carried out in the Korça Agriculture Wholesale Market, and most farmers interviewed come from this region (Table 1) as it is a leading fruit producing area in Albania, accounting for more than half of the country's apple production (GTZ, 2010).

Table 1. Distribution of sample by interview and farm location.

\begin{tabular}{lrrlrr}
\hline $\begin{array}{l}\text { Interview } \\
\text { location }\end{array}$ & \multicolumn{2}{l}{ Farm location } & & & \\
\cline { 2 - 6 } & Korçë & Lushnje & Shkodër & Other & Total \\
& & & & & \\
Korçë & 114 & 0 & 0 & 0 & 114 \\
Lushnje & 0 & 15 & 0 & 9 & 24 \\
Shkodër & 0 & 0 & 9 & 0 & 9 \\
Tiranë & 23 & 0 & 0 & 6 & 29 \\
Other & 1 & 1 & 0 & 1 & 3 \\
Total & 138 & 16 & 9 & 16 & 179 \\
\hline
\end{tabular}

As mentioned, the aim of the research strategy was to identify relatively large, market-oriented farms. About $83 \%$ of the interviewed farmers have orchards that are larger than 0.5 ha. In terms of representativeness, it is estimated that the study sample covers almost $4 \%$ of the group of larger farms with orchards larger than $0.5 \mathrm{ha}$, and $6 \%$ of farms with orchards larger than 0.75 ha. The sample does not include small farms (up to 0.2 ha according to our classification) (Table 2).

The survey data were subject to descriptive statistical analyses. In addition, a cluster analysis was applied in order to identify groups reflecting the different types of attitudes towards contracting. To this aim, the chosen input/ determinant factors are the type of relation (long-term, midterm, short-term versus spot) and contracting behaviour (no contract versus formal contract or informal contract) with wholesale clients, and (horizontal) cooperation in selling (with other farmers). The two-step cluster analysis used is an exploratory, multivariate data analysis technique that allows for the clustering of large data sets with both continuous and categorical attributes (Chiu et al., 2001). The method is based on a probabilistic approach, in which the clustering algorithm uses a likelihood distance measure as the similarity criterion, and the optimal number of clusters is chosen on the basis of Schwarz's Bayesian Inference Criterion (BIC). The main advantage of this unsupervised clustering procedure is essentially that it reduces the effect

\section{Table 2. Distribution of the farm population and sample according to orchard size.}

\begin{tabular}{|c|c|c|c|c|c|}
\hline \multirow[t]{2}{*}{ Size (ha) } & \multicolumn{2}{|c|}{ Population } & \multicolumn{2}{|l|}{ Sample } & \multirow{2}{*}{$\begin{array}{l}\text { Sample/ } \\
\text { population }\end{array}$} \\
\hline & 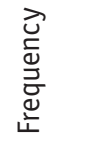 & $\frac{0}{\frac{0}{\sigma}}$ & 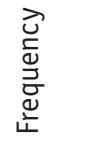 & $\frac{\frac{0}{\sigma}}{\frac{c}{n}}$ & \\
\hline $0-0.2$ & 43,086 & $70.6 \%$ & 0 & $0.0 \%$ & $0.0 \%$ \\
\hline$>0.2-0.3$ & 6,034 & $9.9 \%$ & 6 & $3.4 \%$ & $0.1 \%$ \\
\hline$>0.3-0.4$ & 4,766 & $7.8 \%$ & 10 & $5.6 \%$ & $0.2 \%$ \\
\hline$>0.4-0.5$ & 3,115 & $5.1 \%$ & 14 & $7.8 \%$ & $0.4 \%$ \\
\hline$>0.5-0.75$ & 2,243 & $3.7 \%$ & 34 & $19.0 \%$ & $1.5 \%$ \\
\hline$>0.75-1$ & 1,321 & $2.2 \%$ & 72 & $40.2 \%$ & $5.5 \%$ \\
\hline$>1-1.5$ & 449 & $0.7 \%$ & 41 & $22.9 \%$ & $9.1 \%$ \\
\hline$>1.5-3$ & 36 & $0.1 \%$ & 2 & $1.1 \%$ & $5.6 \%$ \\
\hline Total & 61,050 & $100 \%$ & 179 & $100 \%$ & \\
\hline
\end{tabular}

Source: field survey (for the sample), Ministry of Agriculture Food and Consumer Protection (MAFCP), Statistical Sector, upon request (national population). 
of the researcher's subjective judgement and avoids the arbitrariness of traditional clustering techniques (Norusis, 2003).

The SPSS 19 statistical package (the software used for the analysis), automatically calculates the clustering (number of groups) that best fits the above-mentioned BIC and assigns a silhouette coefficient. The silhouette coefficient is a measure for the clustering quality that is rather independent of the number of clusters $\mathrm{K}$ and can be used to evaluate cluster validity. The value of the silhouette coefficient can vary between -1 and 1 , with a positive value indicating an acceptable quality of the clustering solution. The higher the average silhouette coefficient (or the closer to 1), the 'better' is the clustering (Al-Zoubi and Al Rawai, 2008). Kaufman and Rousseeuw (1990), show that values between 0.7 and

Table 3. Apple destination of use.

\begin{tabular}{lcl}
\hline Product destination & Mean (\%) & Std. Dev. \\
Wholesaler & 68.9 & 8.7 \\
Grocery & 1.2 & 4.0 \\
Specialized retailer & 4.9 & 6.8 \\
Supermarket & 0.6 & 2.5 \\
Processor & 4.7 & 7.3 \\
Households & 0.8 & 2.0 \\
Self-consumption (fresh) & 3.5 & 3.3 \\
Self-processing & 0.3 & 1.4 \\
Loss & 15.0 & 5.6 \\
Total & 100 & \\
\hline
\end{tabular}

1.0 indicate clustering results with excellent separation between clusters, which implies that data points are very close to the centre of their cluster and 'far' from the next nearest cluster.

\section{Results}

The main distribution channels for apples are the wholesalers; farmers in the sample sell most of their products (more than 2/3 on average) to wholesalers. The other attractive channels are specialised fruit and vegetable retailers (hereinafter in this paper these will be referred to as specialized retailers). Other channels appear insignificant (Table 3).

As expected, formal (written) contracts are not common. Only one farmer reported entering into formal contracts with processor clients. Farmers do not use formal contracts with other types of clients such as wholesalers, groceries (typically small convenience shops located within neighbourhoods) and specialised retailers. However, informal agreements exist - about 39\% of the farmers interviewed use largely informal agreements with at least one of the buyer categories (Table 4). Informal agreements are more commonly entered into with retailers and processors; most farmers who supply processors, state that they have informal agreements with them. The existence of informal contracting is less present among respondents (only 12\%) for relations with wholesalers (Table 4). Thus, the trade relations with the type of buyers that absorb most produce from most farms (wholesalers), in most cases ( $88 \%$ of the farms) are not subject to any form of contract (whether formal or informal).

Table 4. Contracting relations by type of clients. ${ }^{1}$

\begin{tabular}{|c|c|c|c|c|c|c|c|c|c|c|}
\hline \multirow[t]{2}{*}{$\begin{array}{l}\text { Type of agreement/ } \\
\text { contracts }\end{array}$} & \multicolumn{2}{|c|}{ All categories } & \multicolumn{2}{|c|}{ Wholesaler } & \multicolumn{2}{|c|}{ Grocery } & \multicolumn{2}{|c|}{$\begin{array}{l}\text { Specialized } \\
\text { retailers }\end{array}$} & \multicolumn{2}{|c|}{ Processor } \\
\hline & 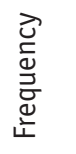 & $\frac{\frac{d}{\pi}}{\frac{\pi}{n}}$ & 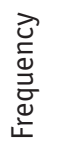 & $\frac{\frac{0}{\sigma}}{\frac{c}{n}}$ & 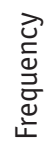 & $\frac{\frac{0}{\sigma}}{\frac{c}{n}}$ & 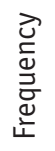 & $\frac{\frac{0}{\sigma}}{\frac{D}{n}}$ & 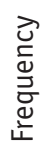 & $\frac{\frac{0}{\sigma}}{\frac{D}{n}}$ \\
\hline No contract/agreement & 109 & $60.9 \%$ & 158 & $88.3 \%$ & 7 & $30.4 \%$ & 52 & $76.5 \%$ & 29 & $40.8 \%$ \\
\hline Written contract & 1 & $0.6 \%$ & 0 & $0.0 \%$ & 0 & $0.0 \%$ & 0 & $0.0 \%$ & 1 & $1.4 \%$ \\
\hline $\begin{array}{l}\text { Unwritten/informal } \\
\text { agreement/contract }\end{array}$ & 69 & $38.5 \%$ & 21 & $11.7 \%$ & 16 & $69.6 \%$ & 16 & $23.5 \%$ & 41 & $57.7 \%$ \\
\hline Total & 179 & $100.0 \%$ & 179 & $100.0 \%$ & 23 & $100.0 \%$ & 68 & $100.0 \%$ & 71 & $100.0 \%$ \\
\hline
\end{tabular}

${ }^{1}$ All surveyed farmers sell to wholesalers, but not all farmers sell to all other types of buyers, such as groceries, specialised fruit and vegetable retailers and processors. 
Farmers were also asked to elaborate on the length of relations with the main buyers of each category. About $79 \%$ of the farmers indicated that their primary dealings with the main wholesaler buyers are on a spot (daily) basis. Only one farmer declared having long-term (longer than 1 year) dealings with the main client wholesalers. The situation is also similar for the relations with specialised fruit and vegetable retailers (green market vendors). Farmers have slightly more stable dealings with the main buyers from the processor and groceries categories, although the two following categories are of lesser importance compared to other channels in terms of sales volumes (Table 5).
It may be expected that farmers that tend to engage in longer-term relations with clients are also more likely to engage in some form of contracting, and vice-versa. Longterm relations with buyers allow for the building up of trust, which is a prerequisite to engage in informal contracts. This is also the case in the surveyed sample, in which the share of farms with an unwritten agreement/contract increases dramatically by moving from spot to long-term relations. This is common to all categories of customers, though it is somehow more evident for processors and wholesalers (Table 6).

Table 5. Length of relations with the main buyers of each category.

\begin{tabular}{|c|c|c|c|c|c|c|c|c|}
\hline & \multicolumn{2}{|c|}{ Wholesaler } & \multicolumn{2}{|c|}{ Grocery } & \multicolumn{2}{|c|}{ Specialized retailers } & \multicolumn{2}{|c|}{ Processor } \\
\hline & 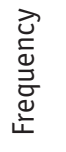 & $\frac{\frac{0}{\sigma}}{\frac{\pi}{n}}$ & 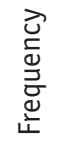 & $\frac{\frac{0}{\sigma}}{\frac{\pi}{n}}$ & 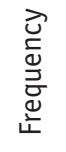 & $\begin{array}{l}\frac{0}{\sigma} \\
\frac{\sim}{\sim}\end{array}$ & 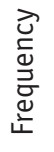 & $\frac{\stackrel{d}{\sigma}}{\frac{\pi}{\sim}}$ \\
\hline Long-term (>1 year) & 1 & $0.6 \%$ & 0 & $0.0 \%$ & 1 & $1.4 \%$ & 1 & $1.4 \%$ \\
\hline Medium-term ( $<1$ year) & 5 & $2.8 \%$ & 5 & $21.7 \%$ & 2 & $2.9 \%$ & 7 & $9.9 \%$ \\
\hline Short-term (month) & 32 & $17.9 \%$ & 16 & $69.6 \%$ & 23 & $33.3 \%$ & 49 & $69.0 \%$ \\
\hline Spot (daily) & 141 & $78.8 \%$ & 2 & $8.7 \%$ & 43 & $62.3 \%$ & 14 & $19.7 \%$ \\
\hline Total & 179 & $100.0 \%$ & 23 & $100.0 \%$ & 69 & $100.0 \%$ & 71 & $100.0 \%$ \\
\hline
\end{tabular}

Table 6. Contract and length of relations within each of the customer categories.

\begin{tabular}{|c|c|c|c|c|c|c|}
\hline & Type of contract & $\begin{array}{l}\text { Long-term } \\
\text { (>1 year) }\end{array}$ & $\begin{array}{l}\text { Medium-term } \\
\text { (<1 year) }\end{array}$ & $\begin{array}{l}\text { Short-term } \\
\text { (month) }\end{array}$ & Spot (daily) & Total \\
\hline \multirow[t]{5}{*}{ Wholesalers } & No contract/agreement & 0 & 1 & 22 & 135 & 158 \\
\hline & Written contract & 0 & 0 & 0 & 0 & 0 \\
\hline & Unwritten agreement/contract & 1 & 4 & 10 & 6 & 21 \\
\hline & Total & 1 & 5 & 32 & 141 & 179 \\
\hline & Chi square $=0.000$ & & & & & \\
\hline \multirow[t]{5}{*}{ Specialized retailers } & No contract/agreement & 1 & 1 & 10 & 40 & 52 \\
\hline & Written contract & 0 & 0 & 0 & 0 & 0 \\
\hline & Unwritten agreement/contract & 0 & 1 & 13 & 2 & 16 \\
\hline & Total & 1 & 2 & 23 & 42 & 68 \\
\hline & Chi square $=0.000$ & & & & & \\
\hline \multirow[t]{5}{*}{ Processors } & No contract/agreement & 0 & 0 & 16 & 13 & 29 \\
\hline & Written contract & 0 & 1 & 0 & 0 & 1 \\
\hline & Unwritten agreement/contract & 1 & 6 & 33 & 1 & 41 \\
\hline & Total & 1 & 7 & 49 & 14 & 71 \\
\hline & Chi square $=0.000$ & & & & & \\
\hline
\end{tabular}


Interviewed farmers were asked to state the reasons for not pursuing formal contracts (choosing two options from a set of multiple choice answers, ranked according to their importance). It appears that unwillingness from the buyers to enter into formal contracts is the main reason as $47 \%$ of the farmers chose it as the first reason while $28 \%$ selected it as the second reason. The other two reasons, ranked by order of importance, are 'difficulty in preparing' contracts and perceived weak contract 'enforcement by courts'. Overall, $17 \%$ of the respondents and $20 \%$ of the respondents rank perceived weak contract 'enforcement by the courts' as respectively the first or second reason for not engaging in formal contracts (Table 7).

More than half the respondents (59\%) consider that informal contracts are more enforceable than formal ones (Table 8). This belief is 'logical' given the high level of distrust in the courts, highlighted in the Introduction Section; whereas trust in social structures that 'guarantee' enforcement of informal contracts tends to be more influential than trust in formal institutions.

Table 7. Reasons for not applying formal contracting.

\begin{tabular}{|c|c|c|c|c|}
\hline \multirow[t]{2}{*}{ Choice } & \multicolumn{2}{|c|}{ First choice } & \multicolumn{2}{|c|}{ Second choice } \\
\hline & 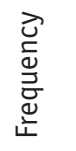 & $\frac{\frac{\infty}{\sigma}}{\frac{c}{n}}$ & 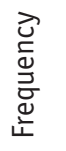 & $\frac{\frac{0}{\pi}}{\frac{1}{n}}$ \\
\hline Buyer does not agree & 85 & $47 \%$ & 51 & $28 \%$ \\
\hline It is difficult to design & 41 & $23 \%$ & 62 & $35 \%$ \\
\hline Not enforced by courts & 31 & $17 \%$ & 36 & $20 \%$ \\
\hline $\begin{array}{l}\text { It is more flexible without } \\
\text { contracts }\end{array}$ & 22 & $12 \%$ & 28 & $16 \%$ \\
\hline 0ther & 0 & $0 \%$ & 2 & $1 \%$ \\
\hline Total & 179 & $100 \%$ & 179 & $100 \%$ \\
\hline
\end{tabular}

Table 8. Answers to the question 'Do you think that informal agreements are more enforceable than formal ones?'

\begin{tabular}{lcc}
\hline Choice & Frequency & Share \\
Yes & 109 & $60.9 \%$ \\
No & 69 & $38.5 \%$ \\
NA & 1 & $0.6 \%$ \\
Total & 266 & 100.0 \\
\hline
\end{tabular}

The cluster analysis yielded two clusters with Silhouette coefficients of about 0.8 (close to 1), which is considered to be a very good clustering (see section on methods). Among the clustering determinant variables, the most important ${ }^{1}$ is the length of the relations (importance $=1$ ), followed by contracting (importance $=0.55$ ) and cooperation in selling (importance $=0.39$ ).

Cluster 1 is the largest cluster, containing almost $71 \%$ of the sample observations. Cluster 2, for its part, contains the remaining 29\% (Table 9). In terms of cluster determinants (input factor), Cluster 1 distinguishes a homogeneous group of farms having only spot activities (with no contracts, or cooperation), from the group having some contracting activities or continuous relationships (Cluster 2). Almost three quarters of farmers in Cluster 2 are engaged in longterm relations with clients. None of the farms in Cluster 1 engage in any form of contracting. All the farms that are engaged in (informal) contracting fall within Cluster 2. However, almost $60 \%$ of farmers in Cluster 2 do not engage in contracting. There is a total of 15 farms (from the entire apple farm survey sample) that reports cooperate selling in a group - all these farms fall within Cluster 2, while Cluster 1 is composed only of farms that market their produce alone.

Several farm characteristics were analysed in conjunction with the identified clusters. The farmer's age, number of years of experience in agriculture, apple production volume and area under plantation do not differ in a statistically significant manner between the two clusters. There are statistically significant differences in losses, number of years of experience and household size. Farmers in Cluster 2 have, on average, more experience in apple production, larger household size and appear to have a lower level of losses compared to those in Cluster 1 (Table 10). The significant difference in the level of losses may imply that engaging in some form of longer relations with clients result in lower losses, while conversely spot market relations result in higher losses.

The most relevant difference between the two clusters can be found in the intention to invest in new plantations in the next three years, revealing a distinctly different perspective for future business development. Indeed, only about $10 \%$ of farmers in Cluster 1 plan to make investments in in new apple plantations in the following 3 years, as compared to $23 \%$ of farmers in Cluster 2 (Table 11). This is consistent with the fact that farmers in Cluster 2 may be exposed to

\footnotetext{
${ }^{1}$ Level of importance ranges between 0 and 1 - the closer to 1 , the more important the given input/determinant factor in the clustering. This coefficient is calculated automatically by SPSS.
} 
Table 9. Results of two-step cluster,

\begin{tabular}{lll}
\hline Category & Clusters & \\
\cline { 2 - 3 } & Cluster 1 & Cluster 2 \\
& & \\
Cluster size & $127(71 \%)$ & $52(29 \%)$ \\
Cluster input/determinant factors & 127 spot & $1(1.9 \%)$ long-term \\
Length & & $5(9.6 \%)$ medium-term \\
& & $32(61.5 \%)$ short-term \\
Contracting/agreement & 127 no contract & $31(26.9 \%)$ spot \\
Cooperation with other farms regarding & 127 no cooperation & $21(40.4 \%)$ informal contract \\
sales & & $37(71.2 \%)$ no cooperation \\
\end{tabular}

Silhouette coefficient $=0.8$.

Table 10. Average age, number of years of experience in agriculture and with apples, apple production area and quantity, losses and number of wholesale clients by cluster.

\begin{tabular}{|c|c|c|c|c|c|}
\hline \multirow[t]{2}{*}{ Variable } & \multicolumn{2}{|l|}{ Cluster 1} & \multicolumn{2}{|l|}{ Cluster 2} & \multirow[t]{2}{*}{ Sign. (T test) } \\
\hline & Average & St. dev. & Average & St. dev. & \\
\hline Age & 47.72 & 9.01 & 48.94 & 5.09 & 0.18 \\
\hline Household size & 5.46 & 1.23 & 6.19 & 1.22 & 0.00 \\
\hline No. of years in agriculture & 22.66 & 6.21 & 22.94 & 6.38 & 0.39 \\
\hline Number of years with apple & 12.51 & 3.29 & 13.46 & 2.98 & 0.04 \\
\hline Apple area size (ha) & 0.66 & 0.32 & 0.61 & 0.20 & 0.18 \\
\hline Apple production size (Mt) & 232.87 & 166.68 & 207.79 & 79.50 & 0.15 \\
\hline Losses & 16.11 & 4.74 & 12.38 & 6.59 & 0.00 \\
\hline
\end{tabular}

Table 11. Answer to the question 'Do you plan any investment in the next 3 years in new apple plantations?'

\begin{tabular}{|c|c|c|c|c|c|c|}
\hline \multirow[t]{2}{*}{ Category } & \multicolumn{2}{|l|}{ Cluster 1} & \multicolumn{2}{|l|}{ Cluster 2} & \multicolumn{2}{|l|}{ Total } \\
\hline & Frequency & Share & Frequency & Share & Frequency & Share \\
\hline Yes & 13 & $10.2 \%$ & 12 & $23.1 \%$ & 25 & $14.0 \%$ \\
\hline No & 114 & $89.8 \%$ & 40 & $76.9 \%$ & 154 & $86.0 \%$ \\
\hline Total & 127 & $100.0 \%$ & 52 & $100.0 \%$ & 179 & $100.0 \%$ \\
\hline
\end{tabular}

Chi square $=0.024$. 
lower uncertainty and transaction costs related to sales and market access (being engaged in longer time-span relations), compared to farmers in Cluster 1.

\section{Discussion and conclusions}

This study constitutes the first examination of the behaviour and relations of Albanian fruit farms with other actors in the value chain. Particular attention was paid to the kind of relations between agricultural producers and buyers, distinguishing between spot markets and longer-term relations, and contracting along the value chain. Given the absence of, or weak, contract enforcement, the analysis of these aspects is of particular interest in transition countries (Ferto and Szabo, 2002).

The survey revealed that formal (written) contracts are not common in the Albanian fruit sector - only one surveyed farmer is engaged in formal contracts. However, informal agreements are common. Indeed, informal contracts are more common in relations with the various categories of retailers and processors.

Another noteworthy aspect is the length of time that relations have existed with the main clients. Most farmers state that their main relations with the premier wholesale buyers are spot based (daily). Farmers tend to have more stable relations with the main buyers from the processor, groceries and supermarket categories, although the two latter categories of distribution channels are less frequent compared to other channels. Farmers who tend to engage in longer relations with clients are also more likely to engage in some form of contracting. Thus, one may conclude that long-term relations may serve as a precondition for informal contracting, given the need for establishing trust (through long-term relations) while informal contracts may serve as a substitute for formal contracts in the context of small farm size and distrust of law enforcement institutions.

Despite small farm size and fragmentation, horizontal cooperation is very limited in Albania in general. One reason is the fact that agricultural cooperation and cooperatives were enforced by the state during the planned economy period and resulted in the impoverishment of cooperative members. In our study, there is a total of 15 farms (about $8 \%$ of the sample) that reports cooperative selling - farmers that tend to engage in longer-term relations with buyers are also more likely to engage in cooperation.

Most farmers state that the main reason for not using formal contracts is that their clients do not prefer them. One potential reason is that the retail sector in the other node of the chain is highly fragmented, and the role of supermarkets (which typically emphasise contracting) is insignificant. The lack of trust in contract enforcement from the courts is another major reason for farmers to avoid entering into formal contracts.

The main limitations of the study rest in: (1) the limited number of observations (though they were not that limited when compared to the population in the area); (2) the basic nature of the contract information analysed (which could have benefited from further details such as contract clauses, duration, production flows, etc.); (3) the simplified elaboration of the results which are only based on a rough identification of major farmer typologies; and (4) the fact that this study analyses the fruit sector only, specifically apple production, and thereby its results may not necessarily be valid for the agriculture sector as a whole. Another potential limitation is the way in which the sample was collected (farmers at the wholesale market), an issue that may have affected answers concerning information about relationships with the other actors in the chain. However, this potential distortion is difficult to assess due to the lack of comparable studies.

All these limitations could also be seen as potential directions for the further development of this research. This study hints at the fact that downstream value chain actors are even less willing than farmers to engage in contracts. The reasons for this are not explored in detail here and this may offer grounds for further research investigating the motivations behind contracting from the point of view of the processors and retailers in Albania.

This would be particularly relevant, as the agrifood value chain is expected to change substantially in the coming years in Albania, due to the fact that the share of supermarkets in the retail sector is expected to increase significantly in number and volume of goods managed, similar to other transition and developing countries. Supermarket chains tend to be demanding of their suppliers with regard to volume, consistency, quality, costs, and commercial practices, which represents a particular challenge for the value chain of perishable food products, including fruits. On the other hand, continuous increases in consumer income will push demand towards higher quality requirements.

In this perspective, the apple (fruit) domestic value chain will need to undergo significant changes to adapt to this new context in order to avoid reliance on imports from betterorganised areas to suit the needs of the new retailers. Our results show that this requires at least two areas of policy action. On the one hand, it is essential that the government, 
donor organisations, and other stakeholders step up with awareness-raising campaigns, addressing all actors of the value chain, regarding market and related institutional developments expected in the near future. On the other hand, law enforcement institutions need to be strengthened in order to enable a favourable environment for contracting (for farmers, wholesalers, retailers and processors).

\section{References}

AAC, 2008. The Albanian apple, value chain, Study Report. Available at: http://pdf.usaid.gov/pdf_docs/PNADN415.pdf.

Almazan, C.V., J.H. Trienekens and J. Bijman, 2011. Sustainable contracts in the bottled tawilis value chain in Taal, Batangas, Philippines. International Journal on Food System Dynamics, 2(4): 420-430.

Al-Zoubi, M. and M. Al Rawi, 2008. An efficient approach for computing silhouette coefficients. Journal of Computer Science, 4(3): 252-255.

Bakucs, L.Z., I. Fertő and G.S. Gábor, 2010. Contractual relationships in the hungarian milk sector. IAMO Forum 2010. Institutions in transition - challenges for new modes of governance, Halle, Germany. Available at: www.iamo.de/fileadmin/uploads/ forum2010/papers_forum2010/Bakucs_IAMO_Forum_2010.pdf.

Bouis, H. and L. Haddad, 1990. Agricultural commercialisation, nutrition and rural poor: a study of Philippine farm households. Lynne Rienner Press Washington, DC, USA.

Catelo M.A.O. and A. Costales, 2008. Contract farming as an institution for integrating rural smallholders in markets for livestock products in developing countries: (I) framework and applications. PPLPI Working Paper 4. FAO, Rome, Italy. Available at: http://www.fao.org/ag/againfo/programmes/en/pplpi/docarc/ rep-0812_contractfarming.pdf.

Chiu, T., D. Fang, J. Chen, Y. Wang and C. Jeris, 2001. A robust and scalable clustering algorithm for mixed type attributes in large database environment. Proceedings of the seventh ACM SIGKDD international conference on knowledge discovery and data mining. ACM, New York, NY, USA, pp. 263-268.

Center for Rural Studies and Sustainable Development (CRSSD), 2005. Customer survey for the Immovable Property Registration System (IPRS), CRSSD, Tirana, Albania.

Fafchamps, M. and S. Lund, 2003. Risk-sharing networks in rural Philippines. Journal of Development Economics, 71(2): 261-87.

Food and Agriculture Organization (FAO), 2001. Contract farming - partnerships for growth. C. Eaton and A. Shepherd (eds.) AGS Bulletin No. 145. FAO, Rome, Italy.

Ferto, I. and G.G. Szabó, 2002. Vertical co-ordination in transition agriculture: a co-operative case study. Discussion Papers, 2002/4. Institute of Economics, Hungarian Academy of Sciences, Budapest, Hungary. Available at: http://econ.core.hu/doc/dp/ dp/mtdp0210.pdf.
Gallup Europe's Balkan Monitor, 2009. Insights and perceptions: voices of the Balkans. Gallup, Brussels, Belgium. Available at: http://www.balkan-monitor.eu/files/BalkanMonitor-2010_ Summary_of_Findings.pdf.

Grandori, A., 1997. An organizational assessment of interfirm coordination modes. Organization Studies, 18(6): 897-925.

Grimard, F., 1997. Household consumption smoothing through ethnic ties: evidence from Cote d'Ivoire. Journal of Development Economics, 53(2): 391-422.

Gesellschaft für Technische Zusammenarbeit (GTZ), 2010. Analysis of fruits and vegetables sector. GTZ, Tirana, Albania.

Gulati, R., 1998. Alliances and networks. Strategic Management Journal, 19: 293-317.

Institute for Development Research and Alternatives (IDRA), 2010. Corruption in Albania, perceptions and experience. USAID Albania, Tirana, Albania. Available at: http://albania.usaid.gov/ shfaqart/465/26/Corruption_in_Albania:_2010_Survey.htm.

Imami. D., E. Skreli, A. Cela and E. Zhllima, 2012. Analysis of consumer preferences for apples in Albania. Ekonomia dhe Agrobiznesi (Economics and Agribusiness), issued by Faculty of Economics and Agribusiness, Agriculture University of Tirana, Vol. 4

Jabbar, M.A., M.H. Rahman, R.K. Talukder and S.K. Raha, 2008. Alternative institutional arrangements for contract farming in poultry production in Bangladesh and their impacts on equity. Research Report 7. International Livestock Research Institute, Nairobi, Kenya.

Kaufman, L. and P. Rousseeuw, 1990. Finding groups in data: an introduction to cluster analysis. Wiley, New York, NY, USA.

Ministria e Bujqësisë, Ushqimit dhe Mbrojtjes së Konsumatorit (MAFCP), 2007. Sector strategy of agriculture and food 20072013, MAFCP, Tirana, Albania.

Ministria e Bujqësisë, Ushqimit dhe Mbrojtjes së Konsumatorit (MAFCP), 2013, National intersectoral strategy for agriculture and rural development, MAFCP, Tirana, Albania.

Nooteboom, B., 1999. The dynamic efficiency of networks. In: Grandori, A. (ed.) Inter-firm networks: organization and industrial competitiveness. Routledge, London, UK, pp. 91-119.

Norusis, M.J., 2003. SPSS 12.0 Statistical Procedures Companion. Prentice-Hall, Upper Saddle River, NJ, USA.

Skreli, E. and D. Imami, 2012. Analyzing consumers' preferences for apple attributes in Albania, applying conjoint choice experiment and latent class analysis. International Food and Agribusiness Management Review, 15 (4): 137-156.

Skreli, E., R. Kola and M. Osmani, 2011. Factors determining collective action in Albanian agriculture: case of apple producers in Albania. Albanian Journal of Agricultural Sciences (AJAS), 10(3): 35-41. 
Stahl, J., T. Sikor, and S. Dorondel, 2009. Transparence de l'administration foncière en Albanie et en Roumanie. (Transparency in the land administration in Albania and Rumania). In: Jouve, A.-M. (ed.) Transitions foncières dans les Balkans: Roumanie, Albanie, Grèce. Options Méditerranéennes (Series A), No. 82. CIHEAM, Paris, France, pp. 55-64.

Watts, M.J., 1994. Life under contract: contract farming, agrarian restructuring, and flexible accumulation. In: Little, P.D. and M.J. Watts (eds.) Living under contract: contract farming and agrarian transformation in sub-Saharan Africa. University of Wisconsin Press, Madison, WI, USA, pp. 21-77.

Williamson, O.E., 1991. Comparative economic organizations: the analysis of discrete structural alternatives. Administrative Science Quarterly, 36: 269-296.

Williamson, O.E., 1979. Transaction-cost economics: the governance of contractual relations. Journal of Law and Economics, 22(2): 233-261.

Williamson, O.E., 1999. Strategy research: governance and competence perspectives. Strategic Management Journal, 20: 1087-1108.

World Bank, 2006. Status of land reform and real property markets in Albania. World Bank, Tirana, Albania.

Zhllima, E. and D. Imami, 2012. The Albanian land rights security perception and factors influencing it. Albanian Journal of Agricultural Sciences, 11(1): 43-52. 